\title{
THE REPORT OF THE 1OTH MEETING OF THE NATIONAL COMMITTEE OF REPRESENTATIVES HELD ON SATURDAY 20 MARCH 1982 IN JOHANNESBURG
}

In the absence of the Chairman, Miss S. Irwin-Carruthers acted as Chairman and welcomed the delegaltes, reminding them of the voting system.

\section{VATIONAL EXECUTIVE COMMITTEE}

Miss Blake read the report. Four ordinary meetings and two special meetings have been held since the last N.C.R. It was agreed that Occupational Physiotherapy and Ergonomics, as well as Excrcise Retrainingshould be offered as post-registration courses. Represcntatives to W.C.P.T. were asked to investigate the possibility of speakers for these , courses. The evaluation of the profession by the Commission for Administration, after the submission of several memoranda, brought to light organisational deficiencies such as a lack of job specilications and work descriptions. The study made of all aspects of the profession by the knowledgeable trained team of evaluators as well as the positive attitude and co-operation by physiotherapists, contributed to a most rewarding experience. A summary of all the information and suggestions received from branches was submitted to the Commission. Discussions with the team covered all aspects of physiotherapy, including private practice and teaching by staff holding joint appointments. Physiotherapists in special schools are not regarded as teachcrs, and although some anomalies still exist it is cxpected that the outcome of the evaluation will stabilise conditions.

Adjustments in salary scales due to the overall increase granted to the Public Service came into effect on I April 1982. Alterations to the salary and carecr structure and conditions of service are to be expected only after the report by the Commission for Administration. Changes in the situation of Physiotherapists in the Defence Force (Permanent Force or military service) are envisaged, but also pend the outcome of the Commission for Administration investigation.

In discussing the problems of physiotherapy in psychiatric hospitals with representatives of the Department of Health, few physiotherapists scem willing to work in psychiatric hospitals, and difficulties are experienced by those physiotherapists in the field due to incomplete knowledge. Methods to overcome these problems are being investigated and the Department of Hcalth will assist by transporting students, as well as with postgraduate in-service training and/or seminars or workshops organised by the Society.

The Hospital Group is processing ideas for an exchange system with physiotherapists from other countries.

During the International Year of Disabled Persons, physiotherapists throughout the country responded well and became involved in many organisations and communities. It is hoped that the International Year of the Aged will evoke the same enthusiasm and participation.

Miss Bowerbank, official representative, and Mrs Macfarlane and Mrs Gilder, ${ }^{*}$ alternate delegates to W.C.P.T., as well as the six speakers who will be presenting papers in Sweden, were wished an enriching and rewarding

\footnotetext{
* Mrs Gilder is no longer able to attend W.C.P.T. and Miss P.

Blake has been appointed as an alternate delegate.
}

visit. The speakers are Miss P. Blake, Mrs M. Bosman, Miss E. A. Freeland, Mr P. Gounden, Mrs G. E. Oosthuizen and Mrs A. Wenham. Mrs Levy, President of the SASP, has been nominated for the second vice-presidency of W.C.P.T. and the Executive Committee of W.C.P.T. have been invited to hold a mecting in South Africa.

\section{REPORT FROM THE PROFESSIONAL BOARD FOR PHYSIOTHERAPY}

Mrs Levy read her report and stressed that all physiotherapists should be registered by the end of March as 103 were in danger of having their names erased.

The Pretoria College of Physiotherapy is now affiliated to the University of Pretoria and offers a degree course, namely a Bachelor in Physiotherapy (B.Phys.T).

Amendments to the latest tariff of fees will be published in the Government Gazette later this year. The proposed amendment to ethical Rulc 21 will be discussed at the forthcoming Medical Council Meeting (the change to ethical Rule 21 had becn accepted at this meeting).

\section{STANDING COMMITTEES}

Mrs Gilder read the report from the Editorial Board and indicated a rise in the cost of production due to rises in printing, addressograph and postage rates. Provisional subjects for forthcoming journals were indicated and contributions invited.

Mrs Victor read the report from the Finance Committee and indicated that R5000,00 has been set aside to assist delegates and speakers who will be attending the Congress in Sweden. The effect of rising air fares on expenses for members of N.E.C. living away from headquarters and the implications of the cost of the public relations project were discussed. Income from various post-registration courses run by the branches of the S.A.S.P. were detailed.

Miss de Bruin read the report from the Registration Committee. The National Diploma has been accepted as the minimal standard for registration and application forms for registration have been designed but the responsibility for sending these out has not yet been finalised.

The Appointments Information Secretary, Miss Blake, indicated that a new information circular has been drawn up. giving details of how to apply for registration. Branch secretaries were requested to send in lists of employing hospitals in their area.

\section{SUB-COMMITTEES}

Miss Roux of the Action Committee read a synopsis of the P.R.O.'s preliminary report and indicated that this would be an ongoing project which could cost the Society approximately R24000. The next step would be to raise this money by voluntary levies, sponsorship, etc.

Miss Irwin-Carruthers read the report from the Constitution Committee and indicated that amendments, when translated, will be printed and made available on request. Further amendments to be submitted to the next N.E.C. meeting. 
Mrs Beenhakker of the Research Committee once more appealed to physiotherapists to write in. in order that research projects may be co-ordinated. Natal Coastal Branch reported on various research projects that were under way (sec articles in this issue). In reporting on the Ad Hoc Committee on the International Year of the Aged Mrs Beenhakker stated that there were many exciting projects in the pipe-line and these should be continued bcyond 1982 . Further information is requested by the committee and members are urged to enhance the public image of the physiotherapist in handling the aged patient.

\section{BRANCH REPORTS}

The delegates from the various branches read their reports, giving information on membership numbers. activities being planned as part of the International Year of the Aged and lectures given, as well as courses. congresses and meetings of affiliated associations which were attended by representatives.

\section{SPECIAL GROUPS/ASSOCIATIONS}

For the Lecturers Group Miss Hendry reported on the degree training at Pretoria, that the University of the Witwatersrand has awarded the first two master's degrees in Physiotherapy and that discussions were held with the Department of Health, pertaining to physiotherapists working with psychiatric patients. Mrs MeFarlane is compiling a history of the Society.

Mrs Cunningham reported that the Manipulative Therapists Group are running 75 hour post-graduate courses on mobilisation and manipulation in conjunction with the Universities of Stellenbosch and the Witwatersrand. The group is still negotiating with I.F.O.M.T. for member-elect status and have extended an invitation to hold the 1984 I.F.O.M.T. international conference in South Africa. A special report on an informal meeting with two members of Parliament, on the Chiropractic Bill, was presented. It emerged that the Bill was passed by a majority of one at its second reading: the Control Board will be chaired by the Minister for Health with five chiropractors and five osteopaths on the Board, and an attempt will be made to have strong controlling measures to limit the scope of the five practising groups concerned.

In the report of the National Hospital Group Miss Farley noted that the post of Chief Physiotherapist has been created and advertised at Transvaal Provincial Administration Head Office. An exchange system with overseas physiotherapists is being investigated. As part of the International Year of the Aged a survey of aged patients receiving hospital physiotherapy will be run.

Mrs Pretorius reported that the Obstetric Association is encouraging research into Fitness in Pregnancy. A new item for obstetric physiotherapy will be recommended to the Tariff Committee of SAMDC.

For the Private Practitioners' Association Mrs Edeling reported that the new tariff of fees has been gazetted (Government Gazette No. 7964 of 24.1 .81 and No. 8005 of 29.1.82) and came into force I February 1982. Government Gazette No. 8029 of 13.2 .82 contains the amended list of registered Medical Aid Schemes.

\section{REPORTS FROM NATIONAL AND INTERNATIONAL ORGANISATIONS}

The National Council for the Care of Cripples will hold its annual Congress in Durban from 20 - 24 September. Mrs
Goodman reported that Mrs Mathias has been elected to the Management Committee of the Cerebral Palsy Division.

Mrs Stewart reported that the National Council for the Care of the Aged issues Brief, an informative newsletter.

Mrs Battison reported on two courses to be run by the S.A. Neurodevelopmental Association: basic NDT course at Brown's School, Pinetown, during July/August 1982 and a course on Early Evaluation and Treatment at Frances Verwerg School in Johannesburg.

Miss Bowerbank gave a short resume of the agenda of the General Meeting of the World Confederation for Physical Therapy to be hold in Sweden in May. Principles of guide lines for specialisation and the rewording of the ethical principles will be discussed. Increase in the annual subscription to WCPT and means of covering travel expenses of the Executive Committee are on the agenda. A motion not to hold the General Meeting concurrently with the Congress, will be submitted.

In the final discussions it was felt that NCR meetings were valuable and that biannual meetings should be continued. The Finance Committee was requested to suggest ways of assisting smaller branches with difficulties in meeting expenses. NEC was asked to investigate the possibility of asking Miss J. Mohr to extend her stay in 1983 in order to run a basic NDT course. The Actions Committee was asked to obtain advice from the PRO firm as regards fund raising. Northern Transvaal Branch still has some copies of the 1981 Congress Proceedings available.

The next meeting of NCR will be in Johannesburg on Saturday 16 October 1982.

\section{COMBINED CONFERENCE TIED INTO COMMONWEALTH GAMES}

Conference ' 82 marks the first time a joint international conference will be held for sport, physical education, recreation and dance. It will also be associated with sports medicine. Conference ' 82 will be held in Brisbane, Australia this year on September 23 to 28, while the Games run from September 30 to October 9.

Sir Roger Bannister, head of the International Council of Sports and Physical Education will deliver the Principal Address: "Science, Health and Sport for All".

Movement and Sport Education is aimed at professionals and academies. Sections include teaching and coaching effectiveness, the needs of the disabled, and dcaling with specific populations.

The Kinesiological aspect of sports sciences will cover biochemistry, biomechanies, physiology, motor behaviour and sport psychology to list a few of the topies. Physiotherapy covers three main themes, namely injury prevention, management of sporting injuries, and care of the ballet dancer. The disabled seetion covers dance. education and movement.

The Recreation section considers the role and function of recreation, its changing forms and processes, as well as its relationship to leisure and work.

Health covers the three areas of care, promotion and prevention of disease. Physical activity, lifestyle and health education will be explored.

For further information contact: Dr. Ian Jobling, Dept of Human Movement Studies, University of Queensland, Brisbane, Australia 4067. 


\section{FISIOTERAPIE KONGRES}

\author{
27 Junie -2 Julie 1983 \\ Plek: \\ Mediese Fakulteit \\ Universiteit Oranje Vrystaat \\ Bloemfontein
}

Tema:

Sewe Lewensstadiums van Fisioterapie

Ons verlang die nuutste Navorsingsinligting met die oog op bogemelde kongres

Stuur asseblief bydraes aan:

Die Kongressek retaresse

Fisioterapie Kongres

Posbus 4345

BLOEMFONTEIN

9300

of

Tel.: $70711 \times 425$ F. Marais

\section{PHYSIOTHERAPY CONGRESS}

\author{
27 June - 2 July 1983 \\ Venue: \\ Medical Faculty \\ University Orange Free State \\ Bloemfontein \\ Theme: \\ Seven Ages of Physiotherapy
}

We require the latest Research information regarding above mentioned congress.

Please send all contributions to:

The Congress Secretary

Physiotherapy Congress

P.O. Box 4345

BLOEMFONTEIN

9300

or

Tel.: $70711 \times 425$ F. Marais

\section{MISSING JOURNALS}

The Journal urgently requires the following issues to bind a second set of all issues printed thus far. One set was handed to N.E.C. at the Council Meeting held in March 1981 in Pretoria and the second set would be retained by the Editorial Board.

All Journals before July 1948 except:

1929-June, September, December

1930-March, June, September

1931-March, June. Deccmber

1932-March. June, September, December

1938 - May

1940 -October.

Also missing:

1949_all journals after March

1950-all Journals

1951 - all Journals between January and October

1952 -all Journals after July

1953 - Journals between April and October

1957 -June

1969-March, June, September and December

1970-March, June. September

1971-March, June, September, December

1972-March, June. September

1973-March, June, September, December

1974-March, June, December

1975 -March, June. September, December

1976 - March.

\section{PHYSICAL THERAPY \\ THE OFFICIAL JOURNAL OF THE AMERICAN PHYSICAL THERAPY ASSOCIATION}

Physical Therapy is published monthly and includes articles of interest to physical therapists, physical therapist assistants and other allied health professionals. Subject matter is divided into three sections: research, practice and administration or education. Recent issucs have included such titles as "Effect of Auditory Rhythm on Muscle Activity", "Management of Patients with Chronic Failure: Role of Physical Therapy" and "Entry Level Education: Concerns about the Proposed Change". Each December we publish a special issue that covers one subject in depth. Last year the subject was respiratory care: the previous special issue was on the knce.

The Journal also contains book reviews, abstracts. information on new products, self-assessment quizzes, a listing of cducational programs and continuing education short-term courses, program information for the various association meetings held each year, and classified advertisements listing job opportunities available throughout the United States and in foreign countries.

Subscription rates are $\$ 28,00$ a year to residents of foreign countries. Single copies are $\$ 3.00$. Send all orders prepaid in US currency to Amcrican Physical Therapy Association. Subscriptions, 1156 15th St NW, Washington, DC 20005. Make drafts payable to APTA. 